смотрением сего собрания? Беспристрастный и любящий свое отечество читатель, тебе сие известно. Но сколько большей пользы ожидать надлежит от сих книг тогда, когда посредством торговли доставляться будут они в отдаленных наших провинииях живущим? [4, с. 150, 153]. Обращение беспристрастный и любящий свое отечество читатель обозначает адресата, тем самым фиксирует диалогичность дискурса.

Идиоглоссы книга, чтение связаны с утилитарной функцией, см.: Наконец вспало на ум, чтобы хотя изданием чужих трудов принесть пользу моим согражданам; «Чтение книг почитаю весьма полезным... Просвещаться наукам и познаниям нужно $[4$, с. 16,15$]$.

Таким образом, в просветительском дискурсе Н.И. Новикова илиоглоссы книга, чтение являются аксиологической основой картины мира. Просветительский дискурс базируется на ключевой идее просвещения русского народа; и педагогической установке просветителя - главным средством воспитания должна стать книга. Создать книгу, напечатать ее, распространить ее по России - таково целеполагание издательской деятельности русского просветителя.

$$
\text { *** }
$$

1. Есин Б.И. Русская газета и газетное дело в России: Задачи и теорет.-методол. принципы изуч. - М.: Изд-во МГУ, 1981. - 132 с.

2. Карасик В.И. Языковой круг: личность, концепты, дискурс. - М.: Гнозис, 2004. -389 с.

3. Караулов Ю.Н. Понятие идиоглоссы и словарь языка Достоевского // Слово Достоевского 2000. Сб. статей / Российская академия наук. Ин-т рус. яз. им. В. Виноградова / Под ред. Ю.Н. Караулова и Е.Л. Гинзбурга. М., 2001. - 896 с.

4. Н. И. Новиков и его современники. Избранные сочинения. - М., 1961. - 532 с.

\title{
Краутман T.E.
}

К вопросу о технике написания и перевода текста закона на английском языке

Крымский филиал Краснодарского университета МВД России (Россия, Симферополь)

doi: $10.18411 / \mathrm{j}-05-2020-164$

idsp: ljournal-05-2020-164

\section{Аннотация}

В статье рассматриваются основные принципы написания и перевода текста закона на английском языке. Отмечается, что текст закона должен обладать структурой, при которой достигается взаимосвязь и взаимозависимость законодательной системы. Выделяются особенности текста закона на синтаксическом и стилистическом уровнях.

Ключевые слова: юридический текст, текст закона, перевод, английский язык

\section{Abstract}

The article discusses the basic principles of writing and translating the text of law in English. It is noted that the text of law should have a structure in which the interconnection and interdependence of the legislative system is achieved. The features of the text of law at the syntactic and stylistic levels are highlighted.

Keywords: legal text, text of the law, translation, the English language

В настоящее время уровень развития законодательной системы каждой страны, а значит и состояние всей юридической системы, отражающей отношение государства к обществу и его стремление к совершенствованию законодательства, расценивается соответственно качеству юридических текстов, разработанности юридической терминологии. При этом перед юристами и лингвистами остро встает задача создания техники написания и перевода текста закона, в основе которых заложены принципы эквивалентности терминологии и точности формулировок, доступности языка текста 
для реципиентов и употребление апробированной системы юридических терминов. Сложность достижения указанной цели зависит от факторов, влияющих на систематичность и унификацию законодательства. Важнейшим является употребление терминологии законодательной системы, то есть возможность интерпретирования одного понятия разными способами, что приводит к смысловой многозначности; затруднение понимания правового значения юридического термина из-за совпадения со словами бытового языка; создание термина в отрыве от общей теории права. Таким образом, сознание единой универсальной терминологической концепции, теоретической и методологической основы терминологической деятельности является приоритетом в современной лингвистике и юриспруденции.

Необходимо отметить, что исследователи, среди которых А.С. Пиголкин, П.В. Рыбин, Б.Н. Климзо, видят специфику английского текста закона, прежде всего, в традициях прецедентного права, позволяющее законодателям, применяя трудные для восприятия формулировки, обеспечить защиту законодательному акту, а также заставить граждан пользоваться услугами юристов в толковании законов. Таким образом, особенность английского юридического языка заключается в использовании сложных синтаксических предложений, большого количества перечислений и оговорок, юридических клише, терминов, архаичных слов и выражений, тавтологии. Отличия между англосаксонской и романо-германской правовыми системами, использование слов и словосочетаний обыденной речи, имеющих иное значение в языке юриспруденции, наличие брака в тексте на английском языке приводит к трудностям перевода и толкования текста закона. По этой причине усилия современной науки направлены на то, чтобы сделать язык юридических документов кратким, точным, ясным для всех слоев общества, сохраняя все элементы для выполнения когнитивной и предписывающей функций.

Решению данной задачи посвящены многочисленные работы профессора А.С. Пиголкина, среди которых «Язык закона» [4], «Теоретические проблемы правотворческой деятельности в СССР» [2] и многие другие, в которых были сформулированы основные принципы законодательной техники. Так требование точности и определенности юридической формы, ясности и доступности языка юридического текста, употребление апробированных терминов, компактность законодательных формул, системность построения права, унификация являются основой для написания текста закона на любом языке. Данные принципы направлены на создание единообразной структуры нормативных актов, при которой обеспечивается взаимосвязь и взаимозависимость всей законодательной системы.

Авторы учебного пособия «Юридический перевод» [3] определяют юридический текст как разновидность двуязычной профессиональной коммуникации, обладающей определенными специфическими свойствами, среди которых содержание в тексте юридически значимой информации; официальный стиль изложения, указывающий на происхождение текста; наличие внешнего оформления, которое придает документу юридическую силу; сопутствующие всем стадиям правового регулирования. Определяя текст закона как разновидность официально-деловых текстов, важнейшими стилевыми характеристиками авторы называют:

- императивность, придающая закону характер предписания;

— точность, являющаяся стилистической нормой и средством устранения многозначности толкования;

- объективность, придающая тексту закона официальное значение, указывающее на волеизъявление всего общества, а не конкретного лица;

- стандартизированность, которая должна проявляться в тексте закона совокупностью формальных элементов документа (юридические клише, фразеологизмы, синтаксические конструкции).

Б.Н. Климзо в работе «Ремесло технического переводчика. Об английском языке, переводе и переводчиках научно-технической литературы» [1] в главе «Перевод 
юридических документов» в работе переводчика юридических текстов важное значение придает изучению, как юридических понятий, так и юридических грамматических конструкций, терминов и штампов, являющихся основой техники перевода юридического текста с английского языка на русский.

Язык законов на английском языке, по мнению Б.Н. Климзо, обладает следующими особенностями, которые станут основой для практического исследования, в основе которого лингвистический анализ текста закона острова Мэн о терроризме и финансировании терроризма («Terrorism and the Financing of Terrorism»), принятый в феврале 2012 года и обновленный 5 февраля 2016 года, закона «Anti-terror law», опубликованном в Турецкой Республике 12 апреля 1991 года:

- синтаксис и стиль юридического текста: несмотря на наличие громоздких предложений в английском тексте закона, при переводе не следует разбивать его на несколько, так как перевод может использоваться в юридических целях, при этом главная мысль выносится в конец предложения; постановка дополнения в падеж, требуемый последним сказуемом в цепочке; определение, стоящее перед цепочкой существительных необходимо при переводе употреблять во множественном числе; модальный глагол shall + смысловой глагол переводится изъявительном наклонением; точно определять функцию причастия прошедшего времени; второй присоединительный союз and переводится как «причем»;

- употребление близких, но не синонимичных понятий, которые возникают в тексте закона из-за перечисления всех понятий, встречавшихся в прецедентах;

— употребление наречий herein / therein и им подобные;

- употребление местоимений it или they для юридических лиц и местоимений he or she для физических лиц;

- употребление who / which, которые заменяются причастием, соответствующем глаголу при переводе на русский язык;

- употребление указательного местоимения any в значении «любой», «какой-либо»;

- употребление местоимения such, которого может опускаться при переводе на русский язык;

- слово-заменитель said и указательное местоимение that переводятся как «указанный» или «этот»;

- the aforesaid (в препозиции к существительному) и above (в постпозиции к существительному) переводятся как «вышеуказанный», the foregoing «вышеизложенный»;

- слова-заменители the former и the latter переводятся как «первый» и «последний»;

- употребление юридических штампов, штампов-моделей, синонимичных штампов, избыточных штампов, устойчивых групп.

$$
\text { **** }
$$

1. Климзо Б.Н. Ремесло технического переводчика. Об английском языке, переводе и переводчиках научно-технической литературы / Б.Н. Климзо // 2-е изд. переработанное и дополненное. - М.: «Р. Валент», 2006. - 508 с.

2. Пиголкин А.С. Теоретические проблемы правотворческой деятельности в СССР / А.С. Пиголкин // дис. ... канд. юрид. наук. - М. 1972. - С. 422.

3. Юридический перевод / под. ред. П.В. Рыбина // Учебное пособие по переводу с английского языка на русский: Издательство «Проспект». - 431 с.

4. Язык закона / С.А. Боголюбов, И.Ф. Казьмин, М.Д. Локшина, С.С. Москвин, А.С. Пиголкин и др.; под ред.: А.С. Пиголкин. - М.: Юрид. лит., 1990. - 192 с. 